\title{
Reliability and Validity of Korean Version of Apraxia Screen of TULIA (K-AST)
}

\author{
Soo Jin Kim, MD, You-Na Yang, MD, Jong Won Lee, MD, Jin-Youn Lee, MD, \\ Eunhwa Jeong, MS, Bo-Ram Kim, MD, PhD, Jongmin Lee, MD, PhD \\ Department of Rehabilitation Medicine, Konkuk University School of Medicine and \\ Konkuk University Medical Center, Seoul, Korea
}

\begin{abstract}
Objective To evaluate the reliability and validity of Korean version of AST (K-AST) as a bedside screening test of apraxia in patients with stroke for early and reliable detection.

Methods AST was translated into Korean, and the translated version received authorization from the author of AST. The performances of K-AST in 26 patients ( 21 males, 5 females; mean age $65.42 \pm 17.31$ years) with stroke (23 ischemic, 3 hemorrhagic) were videotaped. To test the reliability and validity of K-AST, the recorded performances were assessed by two physiatrists and two occupational therapists twice at a 1-week interval. The patient performances at admission in Korean version of Mini-Mental State Examination (K-MMSE), self-care and transfer categories of Functional Independence Measure (FIM), and motor praxis area of Loewenstein Occupational Therapy Cognitive Assessment, the second edition (LOTCA-II) were also evaluated. Scores of motor praxis area of LOTCA-II was used to assess the validity of K-AST.

Results Inter-rater reliabilities were $0.983(\mathrm{p}<0.001)$ at the first assessment and $0.982(\mathrm{p}<0.001)$ at the second assessment. For intra-rater (test-retest) reliabilities, the values of four raters were $0.978(\mathrm{p}<0.001), 0.957(\mathrm{p}<0.001)$, $0.987(\mathrm{p}<0.001)$, and $0.977(\mathrm{p}<0.001)$. K-AST showed significant correlation $(\mathrm{r}=0.758, \mathrm{p}<0.001)$ with motor praxis area of LOTCA-II test. K-AST also showed positive correlations with the total FIM score $(r=0.694, p<0.001)$, the selfcare category of FIM $(r=0.705, p<0.001)$ and the transfer category of FIM $(r=653, p<0.001)$.

Conclusion K-AST is a reliable and valid test for bedside screening of apraxia.
\end{abstract}

Keywords Apraxias, Upper extremity, Stroke, Reproducibility of results

Received September 11, 2015; Accepted February 1, 2016

Corresponding author: Jongmin Lee

Department of Rehabilitation Medicine, Konkuk University Medical Center, 120-1 Neungdong-ro, Gwangjin-gu, Seoul 05030, Korea. Tel: +82-2-20305345, Fax: +82-2-2030-5379, E-mail: leej@kuh.ac.kr

ORCID: Soo Jin Kim (http://orcid.org/0000-0001-6539-6497); You-Na Yang (http://orcid.org/0000-0001-8149-9920); Jong Won Lee (http://orcid. org/0000-0002-0044-6630); Jin-Youn Lee (http://orcid.org/0000-0002-3472-6171); Eunhwa Jeong (http://orcid.org/0000-0003-4331-7369); Bo-Ram Kim (http://orcid.org/0000-0002-5463-1268); Jongmin Lee (http://orcid.org/0000-0001-8718-0099).

(c) This is an open-access article distributed under the terms of the Creative Commons Attribution Non-Commercial License (http://creativecommons.org/ licenses/by-nc/4.0) which permits unrestricted noncommercial use, distribution, and reproduction in any medium, provided the original work is properly cited. Copyright ( 2016 by Korean Academy of Rehabilitation Medicine 


\section{INTRODUCTION}

Apraxia is defined as the inability to correctly perform learned and/or skilled movements not attributable to primary motor and sensory impairments, or language comprehension difficulties [1-3]. Patients with apraxia know what to do, but not how, which manifests as specific spatial and temporal movement errors that interfere with efficient manipulation of objects [4]. Limb apraxia in patients with brain lesion(s) has considerable impact on activities of daily life and heralds a poorer outcome for independent living [5-8]. Therefore, early and reliable detection of apraxia is important for evaluation of patients with brain injury.

Dovern et al. [9] reviewed assessment tools for diagnosis of apraxia in 2012. They found more than 20 assessments for upper limb apraxia having been published during the last four decades. However, many of these tests are not appropriate for clinical use, because some of them focus on only a single apraxic deficit, and some of them do not provide psychometric characteristics, and others are time-consuming. Because of these limitations, most of these assessments have not been widely used as a standard tool for assessment of upper limb apraxia.

For clinical use, the assessment needs to provide quantifiable data and also assess all aspects of apraxia. In addition, the assessment should only take a short time to be used as a bedside screening for early detection. Among the assessments for, Apraxia Screen of TULIA (AST) constructed by Vanbellingen and his colleagues is regarded as an appropriate test for bedside screening of apraxia [9]. AST is based on a more comprehensive assessment of the same study group TULIA (Test for Upper-Limb Apraxia). TULIA consisted of 48 items, and it was designed not to be too time-consuming, but not designed to be used as a bedside assessment of apraxia. AST was constructed by reduction of TULIA to 12 items and also simplifying the scoring system [10] (see Appendix 1). The aim of this study was to evaluate the reliability and validity of the Korean version of AST (K-AST).

\section{MATERIALS AND METHODS}

Translation of Korean version of Apraxia Screen of TULIA into Korean

AST was translated into Korean (Version 1) by two phys- iatrists fluent in English. Another physiatrist reviewed the first version of the translation and then these three physiatrists discussed Version 1. A reconciled version (Version 2) was achieved by consensus and was back-translated into English by two other translators who majored in English literature (Version 3). Version 3 was reviewed and compared to the original version by two physiatrists.

In Version 2, 4 of the 12 items of AST were modified because of the cultural differences. Three items (Items 4, 7 and 8) were substituted with other items in the same domain of TULIA. Item 4 ("smoke a cigarette") was changed to "pick up telephone". Item 7 ("use a stamp to postmark") was changed to "use a key" and Item 8 ("show me as if someone crazy") was changed to "wave goodbye." Item 9 ("make a threatening sign") was modified to "make a 'be quiet' sign," which was created by the translators considering the cultural background of respondents. The back-translated version (Version 3 ) was authorized by the author of AST. Version 2 was then used as Korean version of Apraxia of TULIA (K-AST) (see Appendix 2).

\section{Study population}

The subjects were 26 patients with stroke who were admitted or transferred to the rehabilitation unit of Konkuk University Medical Center from July 2013 to May 2014. The subjects were evaluated with K-AST at admission. Inclusion criteria were recent ( $<1$ month) stroke and ability to perform at least a one-step obey command. Also, the motor power of at least one upper limb needed to be higher than a fair grade for the manual muscle test (MMT) on admission because fair and below fair motor grades could interfere with the AST task. Exclusion criteria were tetraplegia who could not move both sides of their body and limb pain that could affect movement of the limb. The subjects were also simultaneously assessed with Korean version of Mini-Mental State Examination (KMMSE), self-care and transfer categories of Functional Independence Measure (FIM), and motor praxis area of Loewenstein Occupational Therapy Cognitive Assessment, the second edition (LOTCA-II).

\section{Assessment of Korean version of Apraxia of TULIA}

Performances of K-AST for all 26 subjects were videotape-recorded. Two physiatrists and two occupational therapists assessed the videotaped performances twice at a 1-week interval to test the reliability and validity of the 
test. K-AST uses the same scoring system of AST, with a rating from 0 to 12 , which is the summation of each item assessed by a pass (score 1 ) or a fail (score 0 ) grade. The same cut-off score for apraxia was used as in the original version. Same as the original version, the total cut-off score of $<9$ was used for K-AST, and the alternative cutoff score $<5$ for imitation part only was applied in case of severe language comprehension problems.

\section{Other assessments}

Patients were also evaluated with K-MMSE as cognition influences on performance of K-AST items. Self-care and transfer categories of FIM for the subjects were scored to assess independency in activities of daily life. Scores of motor praxis area of LOTCA-II was used to assess the validity of K-AST.

\section{Statistical analyses}

Statistical analyses were conducted using SPSS ver. 17.0 for Windows (SPSS Inc., Chicago, IL, USA). Intraclass correlation coefficient was used to analyze the intra-rater reliabilities and inter-rater reliabilities. Pearson correlation was used to evaluate the validity of K-AST.

\section{RESULTS}

\section{General characteristics of the subjects}

Twenty-six subjects (21 males, 5 females) with stroke were evaluated. Table 1 summarizes their demographics

Table 1. Demographic and baseline characteristics of the 26 patients

\begin{tabular}{|lc}
\hline \multicolumn{1}{c}{ Characteristic } & Value \\
\hline Age (yr) & $65.42 \pm 17.31$ \\
\hline Sex (male:female) & $21: 5$ \\
\hline Type of stroke (ischemic:hemorrhagic) & $23: 3$ \\
\hline Time since stroke onset (day) & $17.90 \pm 10.51$ \\
\hline K-MMSE & $20.23 \pm 6.40$ \\
\hline LOTCA-II ( $\mathrm{n}=23)$ & $10.09 \pm 2.19$ \\
\hline FIM (n=25) & $25.96 \pm 10.89$ \\
\hline
\end{tabular}

Values are presented as mean \pm standard deviation or number of patients.

K-MMSE, Korean version of Mini-Mental State Examination; LOTCA-II, Loewenstein Occupational Therapy Cognitive Assessment 2nd edition; FIM, Functional Independence Measure. and clinical characteristics. The mean age at assessment was $65.42 \pm 17.31$ years. Most of the participants had ischemic stroke $(n=23)$ with 3 having experienced hemorrhagic stroke. K-MMSE scores were obtained from all 26 patients (20.23 \pm 6.40$)$, LOTCA-II scores were assessed from 23 patients $(10.09 \pm 2.19)$, and FIM scores were obtained from 25 patients $(25.96 \pm 10.89)$ on admission.

Intra-rater and inter-rater reliabilities of Korean version of Apraxia of TULIA

The intra-rater and inter-rater reliabilities of the K-AST was analyzed using intraclass correlation coefficient. The intra-rater (test-retest) reliabilities for the four raters were $0.978(\mathrm{p}<0.001), 0.957(\mathrm{p}<0.001), 0.987(\mathrm{p}<0.001)$, and $0.977(\mathrm{p}<0.001)$ (Table 2$)$, which were all very high. The inter-rater reliabilities of the four raters were very high on both assessments; $0.983(\mathrm{p}<0.001)$ at the first assessment and $0.982(\mathrm{p}<0.001)$ at the second assessment (Table 3$)$.

\section{Validity of Korean version of Apraxia of TULIA}

To assess the validity of K-AST, patients were grouped according to AST evaluation cut-off score into an apraxic group (K-AST score $<9$ ) and a non-apraxic group (K-AST score $\geq 9$ ). Grouping assignment for apraxia was done among the subject $(n=21)$ who had all scores for the three parts of the relevant tests (two categories of FIM, and motor praxis area of LOTCA-II). The scores of one patient with severe aphasia were excluded from this assignment. Score difference for LOTCA-II between the two

Table 2. Intra-rater reliabilities

\begin{tabular}{ccc}
\hline & ICC & p-value \\
\hline Rater A & 0.978 & $<0.001^{* * *}$ \\
Rater B & 0.957 & $<0.001^{* * *}$ \\
Rater C & 0.987 & $<0.001^{* * *}$ \\
Rater D & 0.977 & $<0.001^{* * *}$ \\
\hline
\end{tabular}

ICC, intraclass correlation coefficient.

${ }^{* * *} \mathrm{p}<0.001$.

Table 3. Inter-rater reliabilities

\begin{tabular}{lcc}
\hline & ICC & p-value \\
\hline 1st assessment & 0.983 & $<0.001^{* * *}$ \\
2nd assessment & 0.982 & $<0.001^{* * *}$ \\
\hline
\end{tabular}

ICC, intraclass correlation coefficient. ${ }^{* * *} \mathrm{p}<0.001$. 
Table 4. Difference of scores between the apraxic and non-apraxic groups

\begin{tabular}{lccc}
\hline \multicolumn{1}{c}{ Assessment } & $\begin{array}{c}\text { Apraxic } \\
(\mathbf{n}=\mathbf{4})\end{array}$ & $\begin{array}{c}\text { Non-apraxic } \\
(\mathbf{n}=\mathbf{1 7})\end{array}$ & p-value \\
\hline $\begin{array}{l}\text { LOTCA-II } \\
\text { (motor praxis area) }\end{array}$ & $8.50 \pm 0.58$ & $10.88 \pm 1.05$ & $<0.001^{* * *}$ \\
FIM & & & \\
Total $^{\mathrm{a})}$ & $10.75 \pm 0.96$ & $26.53 \pm 8.78$ & $0.002^{* *}$ \\
Self-care $^{\text {Transfer }}$ & $7.00 \pm 0.00$ & $14.82 \pm 3.84$ & $<0.001^{* * *}$ \\
\hline
\end{tabular}

Values are presented $\mathrm{s}$ mean \pm standard deviation.

LOTCA-II, Loewenstein Occupational Therapy Cognitive Assessment 2nd edition; FIM, Functional Independence Measure.

${ }^{a)}$ FIM-total is the sum of scores of self-care and transfer items of FIM.

${ }^{* *} \mathrm{p}<0.01,{ }^{* * *} \mathrm{p}<0.001$.

groups was statistically significant $(\mathrm{p}<0.001)$. FIM scores between the two groups also showed significant difference $(\mathrm{p}<0.05)$ (Table 4). Also, K-AST showed significant positive correlation $(\mathrm{r}=0.758, \mathrm{p}<0.001)$ (Fig. 1 ) with the motor praxis area of LOTCA-II. K-AST also showed positive correlations with total FIM score $(\mathrm{r}=0.694, \mathrm{p}<0.001)$, self-care category of FIM $(r=0.705, p<0.001)$ and transfer category of FIM $(r=653, p<0.001)$.

\section{DISCUSSION}

Apraxia is increasingly recognized as a cognitive motor disorder of stroke with considerable impact on everyday life [5-7]. It is associated with poorer outcome for independent living $[8,11]$ or returning to work [12]. However, until the development of TULIA in 2010, only a few standardized apraxia scales were available, and those did not cover all domains and semantic features of gesture production $[13,14]$. TULIA was designed to be a comprehensive, but not a time-consuming test. However, it was still too long to be used as a bedside test [13]. Recognizing this limitation, AST based on TULIA was developed soon thereafter. The assessment time for AST for most patients is $\leq 2$ minutes, making it suitable as a bedside test.

The aim of this study was to translate AST into Korean and validate it. To perform this goal, 26 stroke patients were assessed with K-AST. The original version of AST was developed in the West and had been verified in English [10]. The translated and modified version with

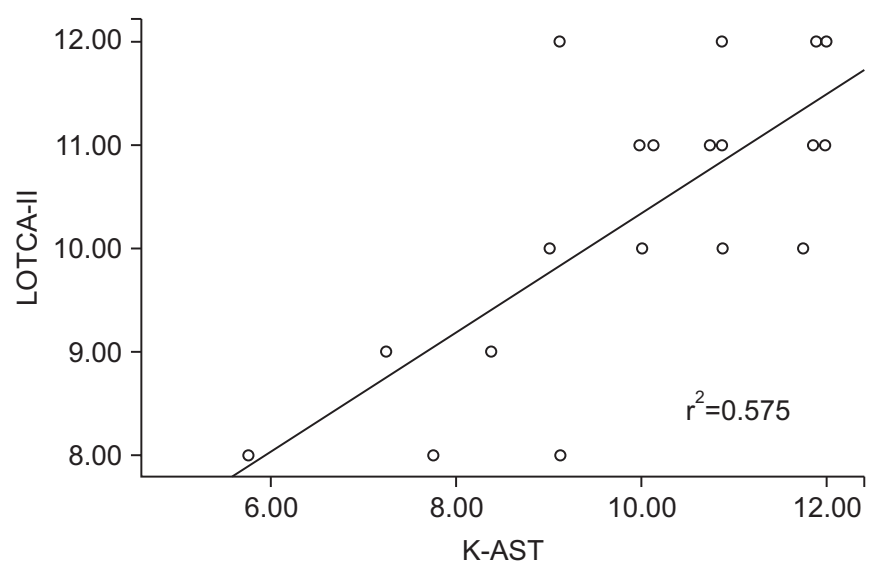

Fig. 1. Correlation of K-AST with motor praxis area of LOTCA-II. The scatterplots show the positive correlation of K-AST with motor praxis area of LOTCA-II. The squared correlation coefficient $\left(\mathrm{r}^{2}\right)$ is 0.575 , which means that approximately $58 \%$ of the patient score for K-AST is directly accounted for by their motor praxis area of LOTCA-II score and vice versa. K-AST, Korean version of AST; LOTCA-II, Loewenstein Occupational Therapy Cognitive Assessment 2nd edition.

adequate internal consistence was applied to Korean patients considering the language and cultural differences. Most of the sentences in the test were simply translated, while 4 items were modified based on context for the cultural differences. The modified version was also authorized by the author of AST. High intra-rater and interrater reliabilities of K-AST were evident and consistent with the original version, indicating the appropriateness in the Korean adaptation of the AST items.

Vanbellingen et al. validated AST with TULIA and reported a highly significant correlation between them [10]. The authors validated TULIA using the De Renzi test, but this scale has not been widely used for assessment of apraxia. We used the score of motor praxis area of LOTCA-II (the second edition of LOTCA) for validating K-AST as a further evaluation. This assessment tool identifies a broad range of cognitive dysfunctions in orientation, visual and spatial perception, motor praxis, visuomotor organization, and thinking operation [15-17]. Among these six areas, the motor praxis area of LOTCA-II consists of three subsets (motor imitation, use of object, and symbolic action). Each subset is rated from 1 to 4 points for a total subset score of 12 , and increasing score indicates better performances [16]. Presently, K-AST positively correlated with motor praxis of LOTCA-II, indicating the ap- 
propriateness of K-AST in evaluating apraxia.

Significant differences were evident between the apraxic and non-apraxic groups in the motor praxis scores of LOTCA-II, self-care and transfer categories of FIM, and the summation of the two categories of FIM. These findings support that the cut-off value of K-AST is appropriate for determining apraxia.

FIM is a widely used method for measuring the level of disability and indicates how much assistance is required for the individual to carry out activities of the daily living [18]. FIM is composed of 18 items, classified in 6 categories. The 18 items of FIM were designed to evaluate the degree of assistance in performing each item, with rating on a 7-point ordinal scale that ranges from total assistance (score 1) to complete independence (score 7). We selected self-care and transfer categories of FIM, which are related to limb movements. The scores of self-care and transfer categories showed significant differences, as predicted.

For the analysis of the apraxic and non-apraxic groups, we excluded one patient with severe aphasia because the different cut-off value was applied to patients with severe language comprehension problems. The original version of AST suggested a patient with language comprehension problems "can be presumed, if three or more amorphous movements occur for pantomime" [10]. For the patient with aphasia in our study who had Wernicke's aphasia, we applied cut-off score $<5$ for determining apraxia. Further analysis for aphasic subjects will require recruitment of a sufficient number of patients.

Among inclusion criteria, ability to perform at least a one-step obey command was used because AST consisted of basic task instructions. All patients included this study were able to perform more than partially two-step obey command tasks. Also, all the tasks did not require upper limb motor power against gravity with significant resistance. Thus, we used "at least higher than a fair grade for one upper limb" as an inclusion criterion. However, all the patients in this study had at least a good grade or higher in one upper limb.

In conclusion, the Korean version of AST displayed significant intra- and inter-rater reliabilities, and correlated significantly to the motor praxis area of LOTCA-II. K-AST showed significant differences for K-MMSE, the motor praxis area of LOTCA-II, and self-care and transfer items of FIM scores between apraxic and non-apraxic groups, based on cut-off value of AST. Therefore, K-AST can be useful as a bedside assessment for early detection of apraxia in Korean patients.

\section{CONFLICT OF INTEREST}

No potential conflict of interest relevant to this article was reported.

\section{REFERENCES}

1. Ochipa C, Gonzalez Rothi LJ. Limb apraxia. Semin Neurol 2000;20:471-8.

2. Heilman KM, Maher LM, Greenwald ML, Rothi LJ. Conceptual apraxia from lateralized lesions. Neurology 1997;49:457-64.

3. De Renzi E, Motti F, Nichelli P. Imitating gestures: a quantitative approach to ideomotor apraxia. Arch Neurol 1980;37:6-10.

4. Wu AJ, Burgard E, Radel J. Inpatient rehabilitation outcomes of patients with apraxia after stroke. Top Stroke Rehabil 2014;21:211-9.

5. Buxbaum LJ, Haaland KY, Hallett M, Wheaton L, Heilman KM, Rodriguez A, et al. Treatment of limb apraxia: moving forward to improved action. Am J Phys Med Rehabil 2008;87:149-61.

6. Hanna-Pladdy B, Heilman KM, Foundas AL. Ecological implications of ideomotor apraxia: evidence from physical activities of daily living. Neurology 2003;60:487-90.

7. Sunderland A, Shinner C. Ideomotor apraxia and functional ability. Cortex 2007;43:359-67.

8. Sundet K, Finset A, Reinvang I. Neuropsychological predictors in stroke rehabilitation. J Clin Exp Neuropsychol 1988;10:363-79.

9. Dovern A, Fink GR, Weiss PH. Diagnosis and treatment of upper limb apraxia. J Neurol 2012;259:126983.

10. Vanbellingen T, Kersten B, Van de Winckel A, Bellion M, Baronti F, Muri R, et al. A new bedside test of gestures in stroke: the apraxia screen of TULIA (AST). J Neurol Neurosurg Psychiatry 2011;82:389-92.

11. Wetter S, Poole JL, Haaland KY. Functional implications of ipsilesional motor deficits after unilateral stroke. Arch Phys Med Rehabil 2005;86:776-81.

12. Saeki S, Hachisuka K. The association between stroke 
location and return to work after first stroke. J Stroke Cerebrovasc Dis 2004;13:160-3.

13. Vanbellingen T, Kersten B, Van Hemelrijk B, Van de Winckel A, Bertschi M, Muri R, et al. Comprehensive assessment of gesture production: a new test of upper limb apraxia (TULIA). Eur J Neurol 2010;17:59-66.

14. Zwinkels A, Geusgens C, van de Sande P, Van Heugten C. Assessment of apraxia: inter-rater reliability of a new apraxia test, association between apraxia and other cognitive deficits and prevalence of apraxia in a rehabilitation setting. Clin Rehabil 2004;18:819-27.

15. Jang Y, Chern JS, Lin KC. Validity of the Loewenstein Occupational Therapy Cognitive Assessment in people with intellectual disabilities. Am J Occup Ther 2009;63:414-22.

16. Itzkovich M, Elazar B, Averbuch S, Katz N. Loewenstein Occupational Therapy Cognitive Assessment (LOTCA) battery. 2nd ed. Pequannock: Maddak; 2000.

17. Lund K, Oestergaard LG, Maribo T. Danish translation and adaptation of Loewenstein Occupational Therapy Cognitive Assessment 2nd edition (LOTCA-II). Scand J Occup Ther 2013;20:302-5.

18. Ottenbacher KJ, Hsu Y, Granger CV, Fiedler RC. The reliability of the functional independence measure: a quantitative review. Arch Phys Med Rehabil 1996;77: 1226-32. 
Appendix 1. Apraxia Screen of TULIA

\section{Apraxia Screen of TULIA}

Name patient:

Test date:

Name examiner:

Diagnosis (incl. lesion localization):

\section{Imitation}

General instruction: "Seven gestures are demonstrated in a mirror fashion, imitate them as precisely as possible"

1. Bring thumb extended on forehead, other fingers point upwards

2. Wipe dust from shoulder

Additional instruction: “For the next five gestures, imagine holding a tool or an object in hand, don't use your fingers as a tool"

\begin{tabular}{|c|c|c|}
\hline & right & left \\
\hline 3. Drink from a glass & & \\
\hline 4. Smoke a cigarette & & \\
\hline 5. Use a hammer & & \\
\hline 6. Use scissors & & \\
\hline 7. Use a stamp to postmark & & \\
\hline
\end{tabular}

\section{Pantomime}

General instruction: "Now gestures are asked. Listen very carefully and perform them as precisely as possible"

\begin{tabular}{|l|c|c|}
\cline { 2 - 3 } \multicolumn{1}{c|}{} & right & \multicolumn{1}{c|}{ left } \\
\hline 8. "Show as if someone is crazy" * & & \\
\hline 9. "Make a threatening sign" ** & & \\
\hline
\end{tabular}

Additional instruction: “Again, imagine holding a tool or an object in hand, don't use the fingers.

\begin{tabular}{|l|c|c|}
\cline { 2 - 3 } \multicolumn{1}{c|}{} & right & left \\
\hline 10. "Brush your teeth" & & \\
\hline 11. "Comb your hair" & & \\
\hline 12. "Use a screwdriver" & & \\
\hline \multicolumn{2}{|c|}{ Total Score } & \\
\cline { 2 - 3 }
\end{tabular}

Item 1 = meaningless; Items 2, 8, 9 = intransitive; Items 3-7 and 10-12 = transitive

*repetitive tapping of the index finger at the temple (rotating movements of index finger are also correct).

${ }^{* *}$ upraised clenched fist (upraised index finger or open hand are also correct). 


\section{A. Test description}

The screening test (Vanbellingen et al., JNNP 2010) comprises 12 items extracted from the more comprehensive test of upper limb apraxia, TULIA (Vanbellingen et al., EJoN 2010) by item reduction analysis. The items represent all semantic categories: one meaningless, three intransitive (communicative) and 8 transitive (tool-related) gestures. In addition, 7 gestures each are tested in the imitation and 5 in the pantomime domain. The 6-point scoring method of TULIA was dichotomized to "fail $=0$ and pass $=1$ ". The cut-off levels of AST were determined in the original sample $(\mathrm{n}=133)$ by comparing the corresponding 12 items from TULIA recoded to pass and fail with the full version. Accordingly, using cut-off levels of 9 and 5, high specificity (93\%) and sensitivity (88\%) for mild and severe apraxia could be estimated.

\section{B. Test situation}

The patient is seated in front of the examiner; both with the forearms placed on the table. Hemiparetic patients execute the gestures with their non-paretic upper limb i.e. ipsilesional. Otherwise both upper limbs are tested. The test performance of the patient is evaluated 'online' during the examination and reported on the scoring sheet (page 1).

\section{Test evaluation}

Dichotomous scale: $\mathbf{0}=$ fail, $\mathbf{1}=$ pass

Maximum score $=\mathbf{1 2}$

Total cut-off score $<\mathbf{9}$ *

Severe apraxia $<\mathbf{5}$

Score $0=$

- Appearance of body part as object errors

- Considerable spatial errors, extra movements and omissions, false end position, substitutions and perseverations

- Amorphous or seeking movements, not related to the desired gesture

Score $1=$

- Normal movement

- Slight slowdown or discrete spatial errors (e.g. diminished amplitude) are allowed

- Discrete extra movements or omissions can occur

- Also when brief substitutions or perseverations occur, which are corrected, the score is still given.

*Alternative cut-off score $<5$ for imitation part only, in case of severe language comprehension problems (can be presumed, if three or more amorphous movements occur for pantomime). 
Appendix 2. Korean Version of Apraxia Screen of TULIA

\section{한국어판 상지 실행증 선별 검사}

환자 이름:

검사일자:

검사자 이름:

진단명(뇌병변 위치 포함):

\section{〈모방과제〉}

검사지침: 지금부터 일곱가지 동작을 보여드릴 것입니다. 당신이 거울을 보고 있는 것처럼 최대한 똑같이 제 행동을 따라 하세요.

1. 엄지손가락을 이마에 대고 나머지 네 손가락은 위를 향하게 두세요

2. 어깨에 먼지를 털 듯 쓸어보세요.

\begin{tabular}{|c|c|}
\hline 우 & 좌 \\
\hline & \\
\hline & \\
\hline
\end{tabular}

추가지침: 다음에 보여드릴 다섯 가지 동작은 당신이 도구나 물건을 손에 들고 있다고 생각하고 그 물건을 직접 사용하는 것처 럼 행동으로 보여주세요. 당신의 손가락을 도구로 사용하지 마세요.

\begin{tabular}{|c|c|c|}
\hline & 우 & 좌 \\
\hline 3. 컵으로 물 마시기 & & \\
\hline 4. 전화 받기 & & \\
\hline 5. 망치질 하기 & & \\
\hline 6. 가위질 하기 & & \\
\hline 7. 열쇠 사용하기 & & \\
\hline
\end{tabular}

\section{〈구두명령〉}

검사지침: 이제부터 행동검사를 시작하겠습니다. 제가 말로 지시하는 사항을 끝까지 듣고 최대한 정확하게 행동으로 보여주세요.

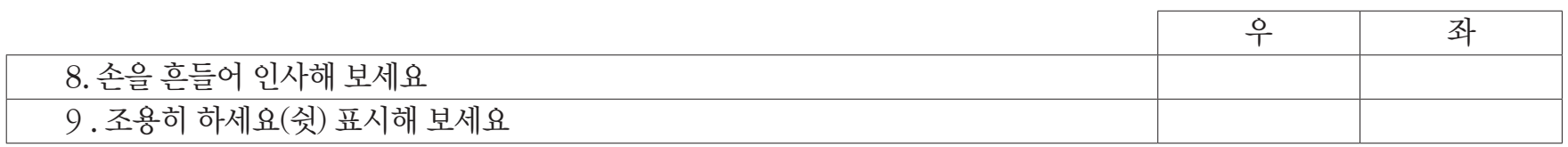

추가 지침: 다시 한 번 말씀 드리겠습니다. 도구나 물건을 손에 들고 있다고 생각하고 행동으로 보여주세요. 손을 도구처럼 사 용하지는 마세요.

\begin{tabular}{|l|c|c|}
\cline { 2 - 3 } \multicolumn{1}{c|}{} & 우 & 좌 \\
\hline 10. 칫솔질을 해보세요 & & \\
\hline 11. 머리를 빗질 해보세요 & & \\
\hline 12. 드라이버를 사용해보세요 & & \\
\hline \multicolumn{2}{|c|}{ 총점 } & \\
\cline { 2 - 3 }
\end{tabular}

항목 1 = 무의미 행동; 항목 2,8,9 = 자동 행동; 항목 3-7, 10-12 = 타동 행동 


\section{A. 검사소개}

본 검사(Vanbellingen 외, JNNP 2010)는 보다 포괄적인 상지 실행증 검사인 TULIA (Vanbellingen 외, EJoN 2010)에서 12개의 항목을 골라서 구성된 축소판 선별 검사입니다. 검사 항목들은 의미론적 분류로 나눠지며 1 가지는 무의미행동, 3 가지는 의미 전달 행동 (자동행동), 8 가지는 도구 사용 행동 (타동 행동)으로 구성이 되어 있습니다. 12 개의 항목 중 7 개의 동작은 모방행동 영역이며 5 개의 동작은 판토마임 영역입니다.

TULIA는 6점의 점수체계를 갖지만 본 검사는 “실패= 0 , 성공= 1 ”으로 이분법적으로 기록합니다. AST의 컷 오프(Cut-off) 수준은 TULIA 검사를 시행한 본 샘플 $(\mathrm{n}=133)$ 에서 얻어졌으며, TULIA중 AST에 해당하는 12 항목을 실패와 성공으로 다시 기록하여 얻어 낸 점수를 비교하여 결정하였습니다. 이를 통하여 결정된 컷 오프(Cut-off) 수준 9점과 5점은 경도 및 중증의 실행증을 평가하는 데 에 높은 특이도(93\%)와 민감도(88\%)를 가집니다.

\section{B. 검사상황}

환자는 테이블 위에 양팔을 편하게 올린 상태로 검사자 앞에 앉습니다. 편마비가 있는 환자는 마비가 없는 상지 (즉 뇌병변측 상 지)로 동작을 수행하고 편마비가 없는 경우에는 양측 상지를 모두 검사합니다. 환자의 수행 정도는 검사를 진행하면서 동시에 평가 하고 점수 기록지(page 1)에 기록한다.

\section{C. 검사 평가}

이분척도: $0=$ 실패, $1=$ 성공

최고점 $=12$

총 컷오프 점수<9

중증 실행증 $<5$

점수 $0=$

- 신체일부를 도구로 사용하는 오류를 보인 경우

- 심각한 공간적 오류, 불필요한 행동 또는 생락, 동작의 방향이 잘못된 경우, 행동의 대체 및 보속행동

- 목표 행동과 관계 없는 비정형적인 행동 혹은 탐색하는 행동

점수 $1=$

- 정상적인 움직임

• 약간의 지연 혹은 공간적 오류(예, 동작 폭의 감소)는 허용된다

- 약간의 불필요한 행동이나 행동 생략은 나타날 수 있다.

- 잠시 대체행동 혹은 반복행동이 나타났으나 수정되었을 때는 점수를 준다.

*언어이해에 심각한 문제가 있는 경우(특히 판토마임 영역에서 세 번 이상 비정형적인 움직임을 보인 경우) 부분 모방과제 수행만 평가하고 컷오프 점수 $<5$ 를 적용한다 